University of Nebraska - Lincoln

DigitalCommons@University of Nebraska - Lincoln

\title{
Color, Cooking Loss and Textural Properties of Patties as Affected by Catfish Belly Flap Mince Size and Cooking Method
}

Jin M. Kim

USDA, Agricultural Research Service, jinmoonkim01@yahoo.com

Bartholomew W. Green

USDA, Agricultural Research Service, bart.green@usda.gov

Follow this and additional works at: https://digitalcommons.unl.edu/usdaarsfacpub

Part of the Agriculture Commons, and the Aquaculture and Fisheries Commons

Kim, Jin M. and Green, Bartholomew W., "Color, Cooking Loss and Textural Properties of Patties as Affected by Catfish Belly Flap Mince Size and Cooking Method" (2007). Publications from USDA-ARS / UNL Faculty. 2474.

https://digitalcommons.unl.edu/usdaarsfacpub/2474

This Article is brought to you for free and open access by the U.S. Department of Agriculture: Agricultural Research Service, Lincoln, Nebraska at DigitalCommons@University of Nebraska - Lincoln. It has been accepted for inclusion in Publications from USDA-ARS / UNL Faculty by an authorized administrator of DigitalCommons@University of Nebraska - Lincoln. 


\title{
Color, Cooking Loss and Textural Properties of Patties as Affected by Catfish Belly Flap Mince Size and Cooking Method
}

\author{
Jin M. Kim \\ Bartholomew Green
}

\begin{abstract}
Patties were prepared with different sizes of channel catfish belly flap mince. Belly flap meat was minced using four different sizes of openings of plate, mixed with salt, formed, and cooked by two methods, in water and oven. Results indicated no differences $(p>0.05)$ in Kramer shear break force in the patties cooked by different methods for the same size of mince. As the size of meat particles for patties decreased, hardness and gumminess increased, and color differed from fillet, but Kramer shear break force as well as percent cooking loss decreased $(p<0.05)$. Patties cooked in an oven showed greater color difference from fillet, percent cooking loss, hardness, and gumminess than those cooked in water for the same size of meat particles $(\mathrm{p}<0.05)$. doi:10.1300/J030v16n01_03 [Article copies available for a fee from The Haworth Document Delivery Service: 1-800-HAWORTH. E-mail address: <docdelivery@ haworthpress.com> Website: <http://www.HaworthPress.com>.]
\end{abstract}

KEYWORDS. Patties, catfish belly flap, mince size, cooking methods, cooking loss, color, texture

Jin M. Kim, $\mathrm{PhD}$, and Bartholomew Green, $\mathrm{PhD}$, are affiliated with the USDAARS Aquaculture Systems Research Unit, Aquaculture/Fisheries Center of Excellence, University of Arkansas, 1200 North University Drive, Pine Bluff, AR 71601.

Address correspondence to: Jin M. Kim, Professor, School of Food Science and Technology, Southern Yangtze University, 1800 Lihu Da Dao, Wuxi, Jiangsu Province, China 214122 (E-mail: jmkim@ @ytu.edu.cn; jinmoonkim01@ yahoo.com).

The authors wish to thank the Arkansas Catfish Promotion Board for partial funding of this study.

Journal of Aquatic Food Product Technology, Vol. 16(1) 2007

Available online at http://jafpt.haworthpress.com doi: $10.1300 / J 030$ v16n01_03 


\section{INTRODUCTION}

Channel catfish (Ictalurus punctatus) is the leading aquaculture product in the US, and consumption of catfish has increased dramatically over the past decade. Processed weight increased from 381 million to 597 million pounds between 1991 and 2001 , and fresh and frozen sales increased from $\$ 417$ million to $\$ 658$ million during the same period (USDA/NASS, 2002). Per-capita consumption of catfish increased from 0.41 pounds in 1985 to 1.15 pounds in 2001, an increase of $180 \%$ (NFI, 2002; Mississippi State University Extension Service, 2002).

As the catfish industry developed, increasing amounts of catfish have been filleted into further-processed, higher value products for marketing. The yield of catfish when processed as whole fillets, is $\sim 40 \%$ (fillet: $32 \%$, belly flap: $7 \%$ ) generating about $60 \%$ by-product (head: $15 \%$, viscera: $22 \%$, frames: $20 \%$, skin: $3 \%$ ) (Redger, 2004), while that of cod orred hake is $\sim 34 \%$, generating about $66 \%$ by-product (head: $16 \%$, viscera: $26 \%$, frames: $24 \%$ ) (Lee, 2004). Consequently, interest is high among processors and researchers in developing higher value products from this by-product, particularly the flesh remaining on the "frames" after filleting (Lee, 1989; Kim et al., 1996). Catfish fillet frames were used to produce surimi (Kim et al., 1996), and catfish surimi was compared with commercial Alaska pollock surimi for their heat-induced gel-forming behavior (Kim et al., 1992).

A recent survey on farm-raised channel catfish consumption in the US indicates the various reasons for which it is not consumed-taste, texture, smell, and lack of preparation knowledge (House et al., 2003). Flavor was not only the most important reason why consumers ate catfish, but it also was the primary reason why non-consumers did not eat catfish. These authors concluded that changing non-consumer perceptions of taste, smell, and texture properties of catfish likely would be difficult. Therefore, developing value-added products that appeal to a broader range of consumers is necessary in order to increase demand for channel catfish in the US.

Fat, moisture, protein, and ash content vary within sections of the fillet of fish (Morkore et al., 2002). During processing, the channel catfish fillet is trimmed to remove the abdominal meat; these trimmings are called belly flap meat. Compared with fillet meat, channel catfish belly flap meat has a high fat content, which limits shelf life and detracts from sensory qualities. Post-harvest handling and processing methods to reduce the channel catfish belly flap meat fat content will enhance the quality, functionality, and sensory characteristics of its value-added products. Adding value to belly flap meat, a low-value product relative to fillets, will increase product utilization and profitability of processing, and possibly increase consumer appeal for channel catfish products.

The mechanism of heat-induced binding of meat particles has been studied extensively under various processing conditions (Vadehra and Baker, 1970; Acton et al., 1983; MacFarlane et al., 1977; Xiong, 1993; Xiong and Blanchard, 1994; McCord et al., 1998). However, only limited published information exists on the binding properties of a series of different sizes of meat particles and its effect on finished product properties. This is particularly true for restructured fish products, where most research has focused on mechanisms of heat-induced binding and gel forming behavior of muscle proteins, myosin, actin, actomyosin, and myosin-subunits (Samejima et al., 1969; Lee and Toledo, 1976; 1979; Niwa et al., 1980; Lee, 1984; Makinodan et al., 1984; Iso et al., 1986; Schwartz and Lee, 1988; Chan et al., 1992; Youngsawatdigul and Park, 1999). Therefore, the objectives of this study were to (1) investigate the feasibility of developing a patty using channel catfish belly flap meat and (2) optimize patty preparation by evaluating the effects of catfish belly flap mince particle size and cooking methods on patty properties.

\section{MATERIALS AND METHODS}

\section{Proximate Analysis}

Channel catfish fillet and belly flap meat samples were subjected to proximate analysis. All samples were dried prior to analysis at $105^{\circ} \mathrm{C}$ for $16 \mathrm{~h}$ in a gravity convection oven (Fisher Isotemp, Fisher Scientific, Pittsburgh, PA) and were cooled in a desiccator. Moisture, crude protein, fat, ash, and carbohydrate were determined using standard procedures (AOAC, 1990).

\section{Patty Preparation}

A $6.8 \mathrm{~kg}$ box of fresh belly flap meat was purchased within $6 \mathrm{~h}$ of production on each of 8 different dates from a commercial catfish processor. Upon receipt, the belly flap meat was divided into four lots and was minced (Model 722, Biro Manufacturing Co. Ltd., Marblehead, $\mathrm{OH}$ ) through one of four different types of plates. The size and number of openings on each $82-\mathrm{mm}$ diameter plate and resultant mince 
were designated S1: three kidney-shaped openings each measuring approximately $18 \times 35 \mathrm{~mm}\left(6.20 \mathrm{~cm}^{2}\right)$; S2: six $18-\mathrm{mm}$ diameter circular openings; S3: 24 9-mm diameter circular openings; and S4: 102 4.5-mm diameter circular openings. Mince was combined immediately with $2 \%$ salt (w/w), mixed (Model KSM150PSOB, KitchenAid, St. Joseph, MI) for $5 \mathrm{~min}$ at low speed $(80 \mathrm{rpm})$, and formed into a patty $(3.5 \mathrm{~cm}$ thickness, $8 \mathrm{~cm}$ diameter) using a hamburger press (Model 1404, Univex, Salem, NH). Each patty was weighed to $220 \mathrm{~g}$. On each date, $2-5$ patties within mince size were assigned randomly to cooking method and textural measurement.

Patties either were cooked in a water bath (W) at $95^{\circ} \mathrm{C}$, or baked (B) in a convection oven (Model OV-350, UNO, Vigodarzare, Italy) at $176^{\circ} \mathrm{C}$. All patties were cooked to an internal temperature of $80^{\circ} \mathrm{C}$. A thermocouple (Model 701, Jenco Electronics, Ltd., San Diego, CA) was inserted into the geometric center of patty to determine the required cooking time for each cooking method. Prior to cooking in the water bath, patties were packed individually in a boil-in-bag and sealed with mild vacuum. Following cooking in the water bath, patties were cooled immediately in running tap water for $20 \mathrm{~min}$. Oven-baked patties were placed immediately in plastic bags and cooled as the boiled patties. Cooled patties were left to equilibrate to room temperature $\left(22^{\circ} \mathrm{C}\right)$ for $24 \mathrm{~h}$ before further analyses.

\section{Cooking Loss}

Following equilibration to room temperature, fluid lost during cooking in the boil-in-bag was drained. Both sides of the patties were then lightly patted with the double layers of paper towel, and patties were weighed. Baked patties were weighed directly. The percent cooking loss was calculated as follows: Cooking loss $(\%)=\left[\left(\mathrm{P}_{i}-\mathrm{P}_{f}\right) / \mathrm{P}_{i}\right] \times 100$, where $\mathrm{P}_{i}=$ patty initial weight $(\mathrm{g})$ and $\mathrm{P}_{f}=$ patty final weight $(\mathrm{g})$.

\section{Color Measurement}

Commission Internationale de I'Eclairage $L^{*}$ (whiteness), $a^{*}$ (redness-greenness), and $b^{*}$ (yellowness-blueness) values of cooked catfish patties were measured using an X-Rite Spectrophotometer (Model SP 62, $\mathrm{X}$-Rite, Grandville, MI). The spectrophotometer was calibrated with an aperture of $4 \mathrm{~mm}$ diameter. Color measurement was carried out directly on the patties. Quadruplicate measurements were performed for each experimental treatment. Total color difference $(\Delta E)$ of cooked catfish patties as compared with a catfish fillet or unprocessed belly flap meat was calculated using the following equation (Woyewoda et al., 1986): $\Delta E=$ $\left[(\Delta L)^{2}+(\Delta a)^{2}+(\Delta b)^{2}\right]^{1 / 2}$. The catfish fillet and unprocessed belly flap meat were cooked in a water bath following the same procedure used for the patties.

\section{Textural Properties}

Shear break force was measured using a Kramer shear cell (internal dimensions of $6.6 \times 7.3 \times 6.4 \mathrm{~cm}, \mathrm{~L} \times \mathrm{W} \times \mathrm{H}$ ) connected to an Instron testing machine (Model 3342, Instron Corporation, Canton, MA). Each cooked patty sample was adjusted to a $6.5-\mathrm{cm}$ diameter and $3.0-\mathrm{cm}$ height for analysis. The Kramer shear cell was equipped with a single, blunt-end blade ( $3 \mathrm{~mm}$ thick) that descended at $5 \mathrm{~mm} / \mathrm{min}$ (Wardlaw et al., 1973; Wheeler et al., 1994, 1996, 1997; Shackelford et al., 1999a, b; Bourne, 2002; Shackelford et al., 2004a, b). Failure point during cuttingshear was reported as Kramer shear break force in Newton.

A compression test was performed using a $10-\mathrm{cm}$ diameter plunger attached to an Instron testing machine (Model 3342, Instron Corporation, Canton, MA). Cooked patties were adjusted to $7.5 \mathrm{~cm}$ diameter and $3.0 \mathrm{~cm}$ height using a circular cutter prepared at a local machine shop and a meat slicer (Model DSL-9, Dito Dean Food Prep, Rocklin, CA). As each patty specimen was compressed to $15 \%$ deformation, the plunger was withdrawn to the original height, the sample was rested for $5 \mathrm{~s}$, and the sample was subjected to a second compression-withdrawal cycle to $15 \%$ deformation. Speed of compression head was adjusted to $5 \mathrm{~mm} / \mathrm{min}$.

The hardness value is the peak force of the first compression (Bourne, 2002). Springiness is how well a product physically springs back after it has been deformed during the first deformation and the percentage of second peak force divided by peak of first peak force (Bourne, 2002). Resilience is a measurement of how a sample recovers from deformation in relation to speed and force derived (Szczeniak, 1963) and is measured as the percentage of the area under the decompression portion divided by the area under the compression portion in the first curve (Bourne, 1978). Cohesiveness is how well the product withstands a second deformation relative to how it behaved under the first deformation (Bourne, 2002), and is measured as the percentage of the area under the compression portion of the second curve divided by the area under the compression portion of the first curve (Bourne, 1966, 1975, 
1976). Gumminess is defined as the product of multiplying hardness and cohesiveness.

\section{Statistical Analysis}

This experiment utilized a split plot design with blocking, where purchase date was the block effect, mince size was the whole-plot factor, and cooking method was the split-plot factor. Data were analyzed using Proc Mixed, a SAS 9.1.3 procedure (SAS Institute, Cary, NC, USA; Littell et al., 1996), where date was treated as a random block effect, and mince size and cooking method were treated as fixed effects. Least squares means were calculated for fixed effects and differences among means were declared significant at $\alpha=0.05$.

\section{RESULTS AND DISCUSSION}

The protein content of fillet (CCF) and unprocessed belly flap meat (CCBFM) did not differ (Table 1). However, fat content was greater and moisture content was lower in belly flap meat compared with fillet meat. Wiles et al. (2004) reported channel catfish belly meat protein, fat, and moisture contents of $16.9 \%, 11.2 \%$, and $72.6 \%$, respectively.

Color differed significantly $(\mathrm{p}<0.05)$ between CCF and patties prepared with CCBFM mince (Table 2). Fillet meat had the highest whiteness $\left(L^{*}\right)$. The darker colors of patties prepared with CCBFM were attributed to dispersion of smeared black peritoneal membrane of belly flap that happened during mincing and mixing with salt. As the size of mince decreased, color difference increased because of a more homogeneous distribution of more finely comminuted black peritoneal membrane particles. Baked patties had greater color difference compared with fillets than patties cooked in water. Slight burning on the surface of

TABLE 1. Proximate analyses (\%) of channel cattish belly flap and fillet meat.

\begin{tabular}{lccccc}
\hline Sample & Protein & Lipid & Carbohydrate & Ash & Moisture \\
\hline Belly flap meat & $15.2^{\mathrm{a}}$ & $11.4^{\mathrm{b}}$ & $0.15^{\mathrm{a}}$ & $0.85^{\mathrm{a}}$ & $72.4^{\mathrm{a}}$ \\
Fillet & $16.1^{\mathrm{a}}$ & $6.6^{\mathrm{a}}$ & $0.18^{\mathrm{a}}$ & $0.82^{\mathrm{a}}$ & $76.3^{\mathrm{b}}$ \\
\hline
\end{tabular}

Values are means of three analyses.

${ }^{a b}$ Means within column followed by different letters are significantly different $(p<0.05)$.
TABLE 2. Color CIE for channel catfish fillet and belly flap meat, and for patties prepared with different size of belly flap meat mince (S1-S4, see text for details) and cooked in a water bath $(W)$ or oven $(B)$.

\begin{tabular}{llccc}
\hline Treatment & $\mathrm{L}^{*}$ & \multicolumn{1}{c}{$\mathrm{a}^{*}$} & $\mathrm{~b}^{\star}$ & Color Difference $(\Delta E)^{1}$ \\
\hline Fillet & 84.2 & -0.86 & 12.24 & \\
Belly Flap Meat & 39.1 & 0.85 & 4.52 & 45.84 \\
S1W & $68.3^{\mathrm{c}}$ & $-1.03^{\mathrm{ab}}$ & $10.55^{\mathrm{a}}$ & $16.00^{\mathrm{b}}$ \\
S2W & $71.7^{\mathrm{d}}$ & $-1.81^{\mathrm{b}}$ & $10.62^{\mathrm{a}}$ & $12.74^{\mathrm{a}}$ \\
S3W & $71.7^{\mathrm{d}}$ & $-1.23^{\mathrm{ab}}$ & $11.08^{\mathrm{a}}$ & $12.58^{\mathrm{a}}$ \\
S4W & $69.3^{\mathrm{cd}}$ & $-1.20^{\mathrm{ab}}$ & $10.63^{\mathrm{a}}$ & $15.09^{\mathrm{ab}}$ \\
S1B & $68.5^{\mathrm{bcd}}$ & $-1.06^{\mathrm{bc}}$ & $15.42^{\mathrm{ab}}$ & $16.77^{\mathrm{b}}$ \\
S2B & $65.0^{\mathrm{ab}}$ & $-0.59^{\mathrm{ac}}$ & $18.39^{\mathrm{bc}}$ & $20.46^{\mathrm{c}}$ \\
S3B & $64.3^{\mathrm{a}}$ & $-0.60^{\mathrm{ac}}$ & $18.86^{\mathrm{bc}}$ & $21.02^{\mathrm{c}}$ \\
S4B & $64.0^{\mathrm{a}}$ & $-0.93^{\mathrm{ab}}$ & $15.32^{\mathrm{ac}}$ & $20.70^{\mathrm{c}}$ \\
\hline
\end{tabular}

Values are means of four observations per duplication.

${ }^{1} \Delta E=\left[(\Delta L)^{2}+(\Delta a)^{2}+(\Delta b)^{2}\right]^{1 / 2} ;$ compared to fillet.

${ }^{a b c d}$ Means within column for patty treatments only followed by different letters are significantly different $(p<0.05)$.

patties during baking may have caused increased values in $\mathrm{b}^{*}$ and $\mathrm{a}^{*}$ as well as decreased value in $\mathrm{L}^{*}$, resulting in increased color difference in baked patties.

Cooking loss (\%) decreased significantly for both cooking methods as mince particle size decreased (Figure 1). This is because particle surface area increases as particle size decreases. Consequently, more myofibrillar proteins are solubilized when finely minced meat is mixed with salt compared with coarsely minced meat. The solubilized myofibrillar proteins bind minced catfish when heat is applied.

In this study, the S4 mince became viscous when mixed with salt because the increased particle surface area resulted in solubilization of a larger amount of myofibrillar proteins. Mechanical beating of S1 particles with salt promotes solubilization of myofibrillar proteins mostly on the surface of the particles. When these CCBFM particles were formed into a patty and cooked, solubilized myofibrillar proteins on the surface of the particles functioned as a binder, but proteins located inside the meat particles remained intact. $S 1$ patty tended to lose more moisture than S4 patty upon cooking. Therefore, it is clear that saltsolubilized myofibrillar proteins hold more moisture than intact myofibrillar proteins when they are subjected to heat-induced gelation. 
FIGURE 1. Cooking loss of patties due to different sizes of meat particles and cooking methods. Belly flap meat was minced through plates with openings of $0.16,0.64,2.54$, or $6.20 \mathrm{~cm}^{2}$.

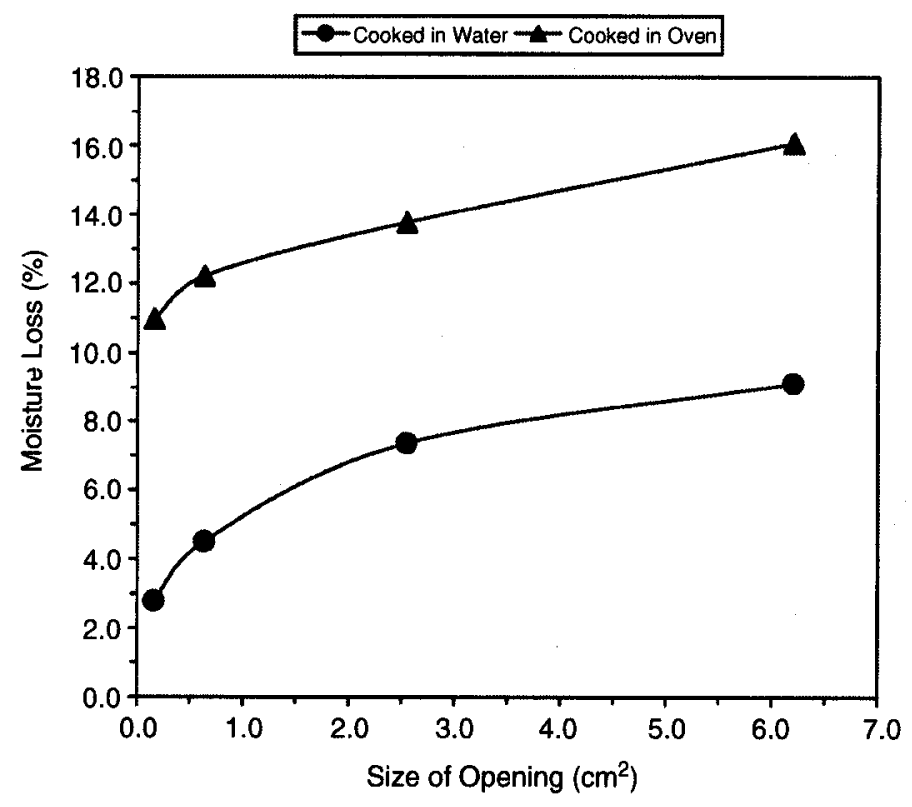

Salt-solubilized myofibrillar proteins on the surface of large mince particles (S1) and whole mince in the case of small mince size (S4) first formed a loose protein network, known as a "suwari" gel between actomyosin and myosin molecules as patty temperature increases from $30^{\circ}$ to $50^{\circ} \mathrm{C}$ (Shimizu et al., 1981; Suzuki, 1981). Actomyosin hydrates and forms a network of hydrogen bonds during "suwari" gelation. Allowing heat-denatured muscle proteins to align and aggregate before further heating, appeared to strengthen the interactions formed during suwari setting (Douglas-Schwarz and Lee, 1988; Roussel and Cheftel, 1988). Additionally, formation of large aggregates through cross-linking of myosin heavy chains is required to form an elastic gel (Niwa et al., 1989; Numakura et al., 1989; Yamashita et al., 1989; Lee et al., 1990; Chan et al., 1992). When patty temperature increases to $50^{\circ}-70^{\circ} \mathrm{C}$, part of gel structure is disrupted; this phenomenon is known as "modori." At temperatures above $70^{\circ} \mathrm{C}$, an elastic protein gel forms as fibrous myofibrillar protein molecules form a network structure, which increases gel strength
(Sano et al., 1990a, b). Hydrogen bonding, hydrophobic bonding (Suzuki, 1981), and S-S bonding (Stone and Stanley, 1992) contributes to increased gel strength. Water is retained in hydrogen and hydrophobic bonds between actomyosin molecules and in the random coils of these molecules that form during heating. As the amount of actomyosin subjected to the gelation process increases, more water becomes trapped in the protein linkages, which results in decreased moisture loss upon cooking.

The Kramer break force decreased significantly within cooking method as the mince particle size decreased (Table 3). However, the Kramer break force within a given mince particle size was unaffected by cooking method. The linkages among protein molecules that occur during gelation of solubilized myofibrillar proteins of finely minced catfish muscle, while strong and elastic, likely lack the structural integrity and resistance to cutting of coarsely minced catfish muscle by a blade in Kramer shear cell.

Contrary to the Kramer break force, the rheological parameters hardness and gumminess increased within cooking method as mince particle size decreased (Table 4). As mentioned earlier, more myofibrillar proteins were extracted when smaller meat particles were mixed with salt because of the increased surface area exposed to salt. Therefore, data in Table 4 indicate that salt-extracted myofibrillar proteins demonstrated higher rheological parameters than intact myofibrillar proteins when denaturation occurs by heat. It has been claimed that cooking yield and binding strength are directly proportional to meat particle surface area in beef rolls (Pepper and Schmidt, 1975; Moore et al., 1976) and chicken loaves (Acton, 1972). Results of the present study on cooking loss (Figure 1) and binding strength (Table 4) are consistent with the earlier studies. Patties cooked in an oven had significantly higher hardness and gumminess compared with those cooked in water (Table 4). This was

TABLE 3. Kramer shear break force $(N)$ for patties prepared with four particle sizes of channel cattish belly flap mince (S1-S4, see text for details) and cooked in a water bath or oven.

\begin{tabular}{lcccc}
\hline & \multicolumn{5}{c}{ Mince Size } \\
\cline { 2 - 5 } Cooking Method & S1 & S2 & S3 & S4 \\
\hline Water Bath & $37.9 \pm 2.06^{\mathrm{a}}$ & $35.9 \pm 1.98^{\mathrm{b}}$ & $33.8 \pm 1.84^{\mathrm{c}}$ & $27.6 \pm 1.96^{\mathrm{d}}$ \\
Oven & $38.2 \pm 2.09^{\mathrm{a}}$ & $34.6 \pm 1.97^{\mathrm{b}}$ & $33.7 \pm 1.99^{\mathrm{c}}$ & $27.1 \pm 1.99^{\mathrm{d}}$ \\
\hline
\end{tabular}

Values are means of four observations per duplication.

${ }^{\text {abcd }}$ Means for patty treatments only followed by different letters are significantly different $(p<0.05)$. 
TABLE 4. Texture profile analysis for patties prepared with one of four particle sizes of channel catfish belly flap mince (S1-S4, see text for details) and cooked in a water bath or oven. Each patty was subjected to two compression cycles to $15 \%$ deformation, with a 5 -s rest between cycles.

\begin{tabular}{lccccc}
\hline & Hardness & Springiness & Resilience & Cohesiveness & Gumminess \\
\cline { 2 - 6 } Treatment & $(\mathrm{N})$ & $(\%)$ & $(\%)$ & $(\%)$ & $(\mathrm{N})$ \\
\hline S1W & $21.0 \pm 0.95^{\mathrm{a}}$ & $96.4 \pm 0.37^{\mathrm{a}}$ & $49.4 \pm 1.00^{\mathrm{a}}$ & $78.3 \pm 0.91^{\mathrm{a}}$ & $16.4 \pm 0.76^{\mathrm{a}}$ \\
S2W & $22.0 \pm 0.94^{\mathrm{b}}$ & $95.7 \pm 0.37^{\mathrm{b}}$ & $48.7 \pm 0.97^{\mathrm{b}}$ & $77.4 \pm 0.89^{\mathrm{b}}$ & $17.1 \pm 0.76^{\mathrm{b}}$ \\
S3W & $25.2 \pm 0.79^{\mathrm{bc}}$ & $95.6 \pm 0.32^{\mathrm{b}}$ & $47.7 \pm 0.87^{\mathrm{c}}$ & $76.7 \pm 0.77^{\mathrm{c}}$ & $19.3 \pm 0.64^{\mathrm{c}}$ \\
S4W & $27.1 \pm 0.98^{\mathrm{d}}$ & $96.2 \pm 0.39^{\mathrm{a}}$ & $47.2 \pm 1.05^{\mathrm{c}}$ & $76.9 \pm 0.95^{\mathrm{c}}$ & $20.9 \pm 0.79^{\mathrm{d}}$ \\
S1B & $23.2 \pm 1.09^{\mathrm{ab}}$ & $96.0 \pm 0.42^{\mathrm{a}}$ & $48.4 \pm 1.10^{\mathrm{b}}$ & $78.6 \pm 1.00^{\mathrm{a}}$ & $18.2 \pm 0.87^{\mathrm{ab}}$ \\
S2B & $25.4 \pm 1.04^{\mathrm{bc}}$ & $95.2 \pm 0.40^{\mathrm{b}}$ & $49.0 \pm 1.05^{\mathrm{a}}$ & $78.1 \pm 0.96^{\mathrm{a}}$ & $19.8 \pm 0.83^{\mathrm{c}}$ \\
S3B & $29.7 \pm 1.00^{\mathrm{cd}}$ & $95.4 \pm 0.38^{\mathrm{b}}$ & $48.9 \pm 0.97^{\mathrm{b}}$ & $77.8 \pm 0.90^{\mathrm{b}}$ & $23.1 \pm 0.80^{\mathrm{bc}}$ \\
S4B & $31.6 \pm 1.04^{\mathrm{bd}}$ & $96.1 \pm 0.40^{\mathrm{a}}$ & $48.0 \pm 1.05^{\mathrm{b}}$ & $78.4 \pm 0.97^{\mathrm{a}}$ & $24.8 \pm 0.83^{\mathrm{bd}}$ \\
\hline
\end{tabular}

Values are means of four observations per duplication.

abcd Means within column for patty treatments only followed by different letters are significantly different $(p<0.05)$.

attributed to a greater loss of water in oven-cooked patties (Figure 1), resulting in further hardening of the patties compared with those cooked in water. However, there was no significant change in patty springiness, cohesiveness, and resilience due to meat particle size or cooking method.

The rheological parameters of meat are drastically changed during heat processing of meat. This is mainly attributed to the thermal denaturation of proteins in the meat, though there are interactions between proteins, lipids, and hydrocarbonate (Iso et al., 1984). Most studies on the rheological properties of fish meat materials are usually limited to those of kamaboko or surimi gel. Unlike surimi and small catfish meat particles in this study (S3 or S4), portions of myofibrillar proteins in large meat particles, which are located inside meat particles (S1 or S2), have not been solubilized during mixing with salt. When denatured, it did not exert resistance upon compression as much as salt-solubilized proteins did (Table 4).

Kauzman (1959) defined protein denaturation as "a process in which the spatial arrangement of the polypeptide chains within the molecule is changed from that typical of the native protein to a more disordered arrangement." This change generally can be represented as a transition from a native (folded) to a denatured (unfolded, disordered state) structure. In the case of carp meat (Iso et al., 1984), rheological parameters decreased sharply until $50^{\circ} \mathrm{C}$, and then they gradually increased. The sharp decrease of the rheological parameters until $50^{\circ} \mathrm{C}$ was attributed mainly to the breaking of intermolecular and intramolecular hydrophobic and hydrogen bonds as a result of thermal denaturation of proteins or by breaking the protein chain by protease. It has been well documented that there are species variations in muscle proteinase activity among fish species (Hashimoto et al., 1982; Iwata et al., 1974; Makinodan et al., 1984).

In fish muscle there exist various proteases. Known ones are cathepspin D (Makinodan, 1982), $\mathrm{Ca}^{++}$-nondependent neutral proteinase (Makinodan, 1984), cathepsin B (Makinodan, 1982), and alkaline proteinase (Iwata et al., 1974). Both the neutral and the alkaline proteinases are unique enzymes that were found originally in fish muscle, and alkaline proteinase is known to be heat stable. There has been no report on muscle proteinase activities in catfish meat. Carp muscle proteins completely attained the change of the structure at $50^{\circ} \mathrm{C}$, but the thermal denaturation of proteins continues until $70^{\circ} \mathrm{C}$. The gradual increase of the rheological parameters after $50^{\circ} \mathrm{C}$ may be attributed to hardening of the carp meat by water loss (Iso et al., 1986). A similar phenomenon was found in pork (Tuomy and Lechner, 1964). Catfish patty in this study was cooked until internal temperature reached $80^{\circ} \mathrm{C}$ resulting in water loss and hardening of patties may have been a little exaggerated. Therefore, differences in water loss and rheological parameters among patties prepared with different sizes of mince particles may have been more distinctive.

\section{CONCLUSIONS}

Differences occurred in color, percent cooking loss, and textural properties, such as Kramer break force, hardness, and gumminess among patties prepared with different sizes of catfish belly flap mince. Results of Kramer shear break force test using a blade indicate higher failure point on patties prepared with larger mince particles. The linkages among protein molecules that occur during gelation of solubilized myofibrillar proteins of finely minced catfish muscle, although strong and elastic, lack the structural integrity and resistance to cutting of coarsely minced catfish muscle by a blade in Kramer shear cell. On the other hand, compression test revealed lower hardness and gumminess for patties prepared with larger mince particles. Data indicate that channel catfish 
belly flap meat has functional properties with potential use for commercial production of fabricated products. Finally, as demand for utilization of by-product generated during filleting grows, other by-products, such as meat recovered from fillet frames, should be investigated further as sources for value-added product development.

\section{REFERENCES}

Acton, J.C. 1972. The effect of meat particle size on extractable protein, cooking loss and binding strength in chicken loaves. J. Food Sci. 37: 240-243.

Acton, J.C., Ziegler, G.R., and Burge, D.L., Jr. 1983. Fuctionality of muscle constituents in the processing of comminuted meat products. CRC Crit. Rev. Food Sci. Nutr. 18: 99-121.

AOAC. 1990. Official Methods of Analysis (15th ed.), Association of Official Analytical Chemists, Arlington, VA.

Bourne, M.C. 1966. A classification of objective methods for measuring texture and consistency of foods. J. Food Sci. 31: 1011-1015.

Bourne, M.C. 1975. Texture properties and evaluations of fabricated foods. In: Fabricated Foods. Inglett, G.E. (Ed.) West Port: AVI Pub Co., p. 127.

Bourne, M.C. 1976. Interpretation of curves from instrumental texture measurements. In: Rheology and Texture in Food Quality. deMan, J.M., Voisey, P.W., Rasper, V.F., and Stanley, D.W. (Eds.) West Port: AVI Pub Co., pp. 244-274.

Bourne, M.C. 1978. Texture profile analysis. Food Technol. 32: 62-66, 72.

Bourne, M.C. 2002. Food Texture and Viscosity: Concept and Measurement. Academic Press, New York.

Chan, J.K., Gill, T.A., and Paulson, A.T. 1992. Cross-linking of myosin heavy chains from cod, herring and silver hake during thermal setting. J. Food Sci. 57(4): 906-912.

Douglas-Schwartz, M. and Lee, C.M. 1988. Comparison of the thermostability of red hake and Alaska pollock surimi during processing. J. Food Sci. 53(5): 1347-1351.

Hashimoto, A., Kobayashi, A., and Arai, K. 1982. Thermal stability of fish myofibrillar Ca-ATPase and adaptation to environmental temperature. Bull. Japan Soc. Sci. Fish. 48: 671-684.

House, L., Hanson, T., Sureshwaren, S., and Selassie, H. 2003. Opinions of U.S. consumers about farm-raised catfish: Results of a 2000-2001 survey. Bulletin 1134. http://www.agecon.msstate.edu/pubs/Papers/Hanson_Catfish_MAFES.pdf

Iso, N., Mizuno, H., Saito, T., Ohzeki, F., and Yang, L.C. 1984. Studies on rheological properties of heated carp meats. Bull. Jap. Soc. Sci. Fish. 50(2): 349-353.

Iso, N., Mizuno, H., Saito, T., Wang, Z., and Narita, M. 1986. The changes in the rheological properties of fish meats during treatment at high temperatures. Bull. Jap. Soc. Sci. Fish. 52(6): 1055-1059.

Iwata, K., Kobayashi, K., and Hase, I. 1974. Studies on muscle alkaline protease--3 distribution of alkaline protease in muscle of fresh water fish, marine fish and internal organs of carp. Bull. Jap. Soc. Sci. Fish. 40: 201-209.
Kauzmann, W. 1959. Some factors in the interpretation of protein denaturation. In "Advances in Protein Chemistry," Vol. 14, p. 1. Academic Press, New York.

Kim, J.M., Jahncke, M., Veal, D., Hearnsberger, J., Eun, J.B., and Liu, S. 1992. Comparison of Alaska pollock and catfish surimi in relation to color and gel-forming behavior. Paper No. 680, presented at 53rd Annual Meeting of Inst of Food Technologists, New Orleans, LA, June 20-24.

Kim, J.M., Liu, C.H., Eun, J.B., Park, J.W., Oshimi, R., Hayashi, K., Ott, B., Aramaki, T., Sekine, M., Horikita, Y., Fujimoto, K., Aikawa, T., Welch, L., and Long, R. 1996. Surimi from fillet frames of channel catfish. J. Food Sci. 61(2): 428-431, 438.

Lee, C.M. 1984. Mechanisms of fat dispersion in comminuted muscle protein matrices. In: Engineering and Food. McKenna, B.M., (Ed.) Elsevier Applied Sci Pub. Vol. 1, pp. 403-414.

Lee, C.M. 1989. Process upgrade for the mechanical recovery of cod frame mince and its cryostabilization. Project Report to New England Fisheries Development Association. Boston, MA.

Lee, C.M. 2004. Personal communication. Food Science and Nutrition Research Center, University of Rhode Island, RI.

Lee, C.M. and Toledo, R.T. 1976. Factors affecting textural characteristics of cooked comminutes fish muscle. J. Food Sci. 41: 391-397.

Lee, C.M. and Toledo, R.T. 1979. Processing and ingredient influence on texture of cooked comminuted fish muscle. J. Food Sci. 44: 1615-1618.

Lee, N., Seki, N., Kato, N., Nakagawa, N., Terui, S., and Arai, K. 1990. Gel forming ability and cross-linking ability of myosin heavy chain in salted meat paste from threadfin bream. Nippon Suisan Gakkaishi. 56(2): 329-336.

Macfarlane, J.J., Schmidt, G.R., and Turner, R.H. 1977. Bonding of meat pieces: A comparison of myosin, actomyosin and sarcoplasmic proteins as binding agents. J. Food Sci. 42(6): 1603-1605.

McCord, A., Smyth, A.B., and O'Neill, E.E. 1998. Heat-induced gelation properties of salt-soluble muscle proteins as affected by non-meat proteins. J. Food Sci. 63: 580-583.

Makinodan, Y. 1982. Properties of fish proteins, changes of fish proteins during storage and processing, and muscle protease. New Food Industry 24: 53-66.

Makinodan, Y., Toyohara, H., and Ikeda, S. 1984. Comparison of muscle proteinase activity among fish species. Comp. Biochem. Physiol. 9B(2): 129-134.

Mississippi State University Extension Service. 2002. "Aquaculture: Catfish." http:// www.msucares.com/aquaculture/catfish/consumer.html

Moore, S.L., Theno, D.M., Anderson, C.R., and Schmidt, G.R. 1976. Effect of salt, phosphate and some nonmeat proteins on binding strength and cook yield of a beef roll. J. Food Sci. 41: 424-426.

Morkore, T., Hansen, A.A., Unander, E., and Einen, O. 2002. Composition, liquid leakage, and mechanical properties of farmed rainbow trout; Variation between fillet sections and the impact of ice and frozen storage. J. Food Sci. 67(5): 1933-1938.

USDA/NASS (National Agricultural Statistical Services). 2002. "Catfish production." NFI (National Fisheries Institute). 2002. "U.S. Consumption of Seafood." http:// www.nfi.org/news/topten.php 
Niwa, E., Koshiba, K., Matsuzaki, M., Nakayama, T., and Hamada, I. 1980. Species-specificities of myosin heavy chain in setting and returning. Bull. Jap. Soc. Sci. Fish. 46(12): 1497-1500.

Niwa, E., Yamada, H., Kanoh, S., and Nakayama, T. 1989. Thermal behavior of actomyosin subunits during setting of salted fish flesh sol. Nippon Suisan Gakkaishi 55(1): $1997-2000$.

Numakura, T., Mizoguchi, R., Kimura, I., Toyoda, K., Fujita, T., Seki, N., and Arai, K. 1989. Changes in gel forming ability and cross-linking ability of myosin heavy chain of Alaska pollock surimi denatured by heat treatment. Nippon Suisan Gakkaishi 55(6): 1083-1090.

Pepper, F.H. and Schmidt, G.R. 1975. Effect of blending time, salt, phosphate and hot-boned beef on binding strength and cook yield of beef rolls. J. Food Sci. 46: 227-230.

Redger, J. 2004. Personal communication. Delta Supreme Fish Processors. Dumas, AR.

Roussel, H. and Cheftel, J.C. 1988. Characteristics of surimi and kamaboko from sardines. Int. J. Food Sci. Technol. 23: 607.

Samejima, K., Hashimoto, Y., Yasui, T., and Fukazawa, T. 1969. Heat gelling properties of myosin, actin, actomyosin and myosin-subunits in a saline model system. J. Food Sci. 34: 242-245.

Sano, T., Noguchi, S.F., Matsumoto, J.J., and Tsuchiya, T. 1990a. Effect of ionic strength on dynamic viscoelastic behaviour of myosin during thermal gelation. J. Food Sci. 55: 51-54.

Sano, T., Noguchi, S.F., Matsumoto, J.J., and Tsuchiya, T. 1990b. Thermal gelation characteristics of myosin sub-fragments. J. Food Sci. 55: 55-58, 70

SAS. 1990. Version 8, SAS Institute, Cary, North Carolina.

Shackelford, S.D., Wheeler, T.L., and Koohmaraie, M. 1999a. Evaluation of slice shear force as an objective method of assessing beef longissimus tenderness. J. Anim. Sci. 77: 2693-2699.

Shackelford, S.D., Wheeler, T.L., and Koohmaraie, M. 1999b. Tenderness classification of beef: II. Design and analysis of a system to measure beef longissimus shear force under commercial processing conditions. J. Anim. Sci. 77: 1474-1481.

Shackelford, S.D., Wheeler, T.L., and Koohmaraie, M. 2004a. Evaluation of sampling, cookery, and shear force protocols for objective evaluation of lamb longissimus tenderness. J. Anim. Sci. 82: 802-807.

Shackelford, S.D., Wheeler, T.L., and Koohmaraie, M. 2004b. Technical note: Use of belt grill cookery and slice shear force for assessment of pork longissimuss tenderness. J. Anim. Sci. 82: 238-241.

Shimizu, Y., Machida, R., and Takenami, S. 1981. Species variation in the gel-forming characteristics of fish meat paste. Nippon Suisan Gakkaishi 47: 95-104.

Stone, A.P. and Stanley, D.W. 1992. Mechanisms of fish muscle gelation. Food Res. Int. 25: 381-388.

Suzuki, T. 1981. Fish and Krill Protein: Processing Technology, Applied Science publishers Ltd. London.

Szczesniak, A.S. 1963. Classification of textural characteristics. J. Food Sci. 28: 385-389.
Tuomy, J.M. and Lechner, R.J. 1964. Effect of cooking temperature and time on the tenderness of pork. Food Technol. 18: 219-222.

Vadehra, D.V. and Baker, R.C. 1970. The mechanism of heat initiated binding of poultry meat. Food Technol. 24: 42-55.

Wardlaw, F.B., McCaskill, L.H., and Acton, J.C. 1973. Effect of postmortem muscle changes on poultry meat loaf properties. J. Food Sci. 38: 421-423.

Wheeler, T.L., Koohmaraie, M., Cundiff, V., and Dikeman, M.E. 1994. Effect of cooking and shearing methodology on variation in Warner-Bratzler shear force values in beef. J. Anim. Sci. 72: 2325-2330.

Wheeler, T.L., Shackelford, S.D., and Koohmaraie, M. 1996. Sampling, cooking and coring effects on Warner-Bratzler shear force values in beef. J. Anim. Sci. 74 $1553-1562$.

Wheeler, T.L., Shackelford, S.D., Johnson, P., Miller, M.F., Miller, R.K., and Koohmaraie, M. 1997. A comparison of Warner-Bratzler shear force assessment within and among institutions. J. Anim. Sci. 75: 2423-2432

Wheeler, T.L., Shackelford, S.D., and Koohmaraie, M. 2000. Variation in proteolysis, sarcomere length, collagen content, and tenderness among major pork muscles. J. Anim. Sci. 78: 958-965.

Wiles, J.L., Green, B.W., and Bryant, R. 2004. Texture profile analysis and composition of a minced catfish product. J. Text. Stud. 35: 325-337.

Woyewoda, A.D., Shaw, S.J., Ke, P.J., and Burns, B.G. 1986. Recommended Laboratory Methods for Assessment of Fish Quality. Canadian Technical Report of Fisheries \& Aquatic Sciences, August No. 1448.

Xiong, Y.L. 1993. A comparison of the rheological characteristics of different fractions of chicken myofibrillar proteins. J. Food Biochem. 16: 217-227.

Xiong, Y.L. and Blanchard, S.P. 1994. Myofibrillar protein gelation: Viscoelastic changes related to heating procedures. J. Food Sci. 59: 734-738.

Yamashita, R., Tanaka, M., Nagashima, Y., and Taguchi, T. 1989. Effects of cross linker on thermal gelation of oval filefish muscle proteins. Nippon Suisan Gakkaishi 55(5): 891-895.

Yongsawatdigul, J. and Park, J.W. 1999. Thermal aggregation and dynamic rheological properties of Pacific whiting and cod myosins as affected by heating rate. J. Food Sci. 64(4): 679-683.

doi:10.1300/J030v16n01_03 